\title{
Civilisational analysis and intercultural models of American societies.
}

The critical reconstruction of classical perspectives and World history as contemporary civilisational analysis brings a fresh and alternative approach to twenty-first century social science. It has been a robust basis for critique of existing conservative scholarship of civilisations of the Samuel's Huntington's variety. What has variously emerged from the work of scholars in this field is a conceptual re-composition of sociological theory with a heightened intercultural sensibility. The contentious notion of civilisation remains, however, despite its uses and abuses in current-day political discourse. Indeed, it is reaffirmed as an alternative prism of understanding to the globalisation paradigm which today seems to be receding. This paper aims to explore how far the critical reconsideration of civilisation goes in achieving intercultural goals that are set for it by its key thinkers. It pays particular attention to the Atlantic sphere. The paper concludes that there are pressing reasons, and great potential, for further conceptual clarification in this field.

Jeremy Smith

School of Behavioural and Social Sciences and Humanities

University of Ballarat,

P O Box 663

Victoria, Australia

jeremy.smith@ballarat.edu.au 
Jeremy Smith works in the School of Behavioural and Social Sciences and Humanities at the University of Ballarat. He researches in the areas of civilizations analysis and modernity in relation to the Americas and Japan. He is author of Europe and the Americas: State formation, Capitalism and Civilizations in Atlantic Modernity (Leiden: Brill) and numerous articles on Japan and on the Americas. 


\section{Introduction: opening the intercultural in civilisations analysis}

This article presents a report on the state of civilisations analysis in sociology. Contemporary civilisations analysis traces its beginnings through historical and comparative sociology to growing interest in the 1980s in the so-called Axial Age. During the 1990s a conceptual recomposition of sociological theory variously emerged from the work of scholars in this field, including representative figures such as Said Arjomand, Johann Arnason, Randall Collins, Shmuel Eisenstadt, Bruce Mazlish, Edward Tiryakian and Bjorn Wittrock. The results are infused with a heightened intercultural sensibility which, nonetheless, does not dispense with the contentious notion of civilisation. The aim of the current essay is a preliminary assessment of the success of this emerging field in forging a more adequate scholarship of interculturality. It focuses mainly on the work of two of its highest profile scholars: Johann Arnason and Shmuel Eisenstadt. In this context, examination of Japanese modernity and the case of Islam (as suggested in Said Arjomand's analyses) illustrates the potential for thinking about the intercultural from the point of view of civilisations analysis. A lengthier consideration of Atlantic modernity, its colonial forms of power and the status of its indigenous civilizations show up some of the existing limitations of a civilisational approach. The essay concludes that there are pressing reasons, and great potential, for further conceptual clarification and more research in this field

Civilisational analysis started in the 1990s with critical assessment of pre-war scholarship in World History, a reconsideration of the globalisation paradigm and a reinterpretation of classical social theory (Arjomand and Tiryakian 1-11). There was a feeling that the concept of ‘civilisation’ had value, but that it was ideologically-loaded. Suspicion of Eurocentricism dogged 
this rarely-irreproachable word. Earlier insights that pointed a way out of this malaise by Weber, Durkheim, Elias and Mauss were overlooked in postwar sociology's 'retreat into the present' (as Elias put it) and the time had come to re-visit them. A related task was to re-trace the etymological origins of the family of words that preceded and informed the term (Rundell and Mennell 6-8). The groundwork had been laid by Norbert Elias, Carl Brinkman and Lucien Febvre in the interwar period. Once retrieved by contemporary civilisations theory in the era of growing post-colonial sensibilities both this lexicology and the earlier and neglected works of sociology and anthropology assumed fresh significance. The new environment in the social sciences compelled reflection on the political connotations of the body of concepts in earlier historical and sociological writings. As a result, greater emphasis fell on the pluralistic conception of civilisation (Arnason "Social theory"). At the same time, new comparative histories of non Western societies stimulated the search for a non-universalistic basis for researching relationships between countries and regions. In the wake of the cultural turn, some comparative sociologists sought a non-culturalist framework that would do justice to the range of historical formations whilst being able to shed light on the interaction between them. The accent of this kind of research program fell on the plurality of forms of human organisation and the dynamism of their interaction. Its proponents distrusted the portrayal of many non-Western civilisations as secluded, unvarying and insular, an impression frequently associated with Huntington's scholarship. Due to the general non-culturalism of this body of research and the emphasis on interactivity, I argue that civilisational analysis promises a productive vantage point for scholars of intercultural perspectives.

\section{Intercultural trends in Arnason's civilisational paradigm}


Johann Arnason's comparative research program has chronicled the development of this 'paradigm in the making' (“Civilizational analysis”), debated its unresolved questions (“Civilizations in dispute") and developed substantive interventions around particular civilisations, such as Japan ("Social theory and Japanese experience") and Islamiciate civilisations ("Marshall Hodgson’s civilisational analysis"). The specific interest of the current essay lies in two ways of thinking about forms of the intercultural that can be discerned in his work. One kind is overtly hermeneutic and interpretive; the other involves the intercivilisational encounters at the heart of multisocietal formations. Each is examined in turn below after a short outline of the premise of Arnason's theoretical strategy is set down.

An essential post-Weberian premise underpins this dimension of Arnason's oeuvre. Early on, he promoted pluralistic models at the inception of his social theory of civilisations where he turned to classical sources. Three thinkers stand out from this phase. Weber's curtailed insights developed in his sociology of religious worlds implied a pluralism that was never fully theorised as civilisational analysis. In contrast, Durkheim and Mauss' instructive notes on civilisation (along with Mauss' later essay on elements and forms) worked more determinedly against a unitary conception that generalised key evolutionary patterns across different historical figurations. Durkheim and Mauss' notes therefore acted as a point of contemporary resumption of discussion about multiple supra-societal forms, or 'families' of societies. Both singular and pluralistic conceptions were present in the history of European thought, but it was the former that was ideologically dominant. In contrast, the pluralistic conception was often buried in discussions about culture. This problem was variously taken up by later scholars of World History, such as Toynbee, Borkenau and Spengler. Their preoccupation with typology 
represented an advance on the singular idea of civilisations, but still did not shed much light on the dimension of interaction of large-scale historical formations.

Contemporary approaches alert to the best and more serious works of post-colonial critique could not suffer a conception of civilisation taken in the singular; this has been a vital part of Arnason's agenda from early studies through present works. During the course of exploring Japan, Byzantium, East Asia, Islam civilisation, Greece, India, South East Asian civilisation and the questions of a Eurasian era and Axial transformations, Arnason takes this awareness of irreducible plurality to the study of two sharply defined kinds of interculturality. The first kind both articulates and departs from Eisenstadt's civilisational analysis. A brief discussion will help illustrate Arnason's unique contribution to an interpretive notion of civilisation. The point of contact is Eisenstadt's analysis of different cultural ontologies, or ways of conceiving and thereby 'making' the world. For him, these are the key problematic as much as different economic systems, patterns of government and rulership or formation of collective identities. Eisenstadt's approach sits at the cusp of two further conceptions of what civilisation is that are considered in this essay. One conception is 'objectivistic'; the other has to do with an imaginary horizon. The objectivistic looks for civilisations where there is differentiation in the things that they produce — the objects of art, architecture, writing, legal codes, cities and tangible institutions. ${ }^{1}$ Their visible complexity can be catalogued and denoted as 'civilised' in comparison with the pre-civil or primitive. As Spengler said pithily in defining a society in decline, a culture becomes a civilisation when it "suddenly hardens...it mortifies, its blood congeals...” (310). Its objectivity is then apparent. As these things are generated over space and in places, it seems sensible to look for them in areas, regions and continents. Civilisations are thereby distinguished by the overall forms of objectified organisation best summed up as leading 
economies and states. The central criticism that can be launched at this notion of civilisation is that it risks emphasizing an over-integrated notion of cultural constellation. One might say that this is akin to Dennis Wrong's critique of the oversocialised concept of humanity as it has emerged in the history of sociological thought. Indeed, there are direct parallels between the objectivistic and over-integrative concept of civilisation and the 'society' which is the target of Wrong's analysis. This may be consistent with a plural conception of civilisation but it risks the implication that civilisations are discrete, slow-changing and separate units. Eisenstadt's notion of civilisation is not distanced too greatly from the objectivistic perspective, as I establish in the last section.

The second conception comes from an interpretation of Castoriadis’ work on the social imaginary and connects with a post-phenomenological view of intercultural engagement. It is expressed in some minor notes in Arnason's work major work on civilisational theory. He points to an imaginary horizon which is civilisational and which informs the constitution of social life. This hints at an openly Castoriadian line of argument, but Arnason does not develop it any further. This could be articulated in terms of a thesis: the diversity of civilisations is due to imaginary significations (the most fundamental symbolic forms of meaning) that are 'of a particularly complex, durable and distinctive kind' (“Civilizations in dispute” 205) capable of generating 'more circumscribed universes of meaning' (206). In other words, civilisations are distinguished and distinguishable by long-standing and broader codes of meaning that extend beyond national cultures. I think that this can be extended to the notion of a civilisational imaginary, or imaginaries, which give a sense of civilisation and mark out the symbols by which Europeans came to distinguish civilisational forms. 
To carry this argument forward, I want to outline the historical scenario of Atlantic modernity, which was one of the crucial zones in which Western notions of civilisations coalesced. My argument is that the concepts of civilisation that have formed at the heart of Western self-understanding are derived from a deeper intuition that pre-dated the development of a family of words denoting civilisation. There are two crucial phases: the sixteenth century 'discovery' of Americans worlds and eighteenth century clashes over the disdain of the New World. Sixteenth century debates about the biblical significance of the American New World and its anthropological and botanical characteristics reveal a differentiating consciousness of civilisation. Initially, the Americas and its peoples and places were regarded with naïve and benign curiosity which led to a quest for similarities. Classical analogies drew out resemblances, but could not obscure obvious differences in languages, social organisation and cosmologies of meaning. During this phase was all-things American were regarded with comparative sympathy. This did not negate processes of colonisation underway nor did it displace scientific classification that aided the seizure of territory and transformation of the environment. It inaugurated a dramatic horizon of civilisational difference between Europeans and the indigeneity of the American world. Ideologies around this consciousness had not formed as fully as they would later. Moreover, there was no vernacular through which Europeans unambiguously voiced an ideal of civilisation endowed with the principles of progress and exceptionality. However the conceptual signage that reinforced European consciousness of civilisations had materialized; the premises of 'the self-consciousness of the West' in Elias' words (3) coalesced.

A similar consciousness was evident in the eighteenth century. But the framework for reflection about civilisation was ideologically more clearly rooted. Images of civilisational difference circumscribed the philosophical defence of Europe's empires against the opponents of 
colonialism who, for their own part, exercised a notion of culture. Both sides shared a common horizon in the contours of civilisational thinking which provided paradigmatic coherence for both sides of Europe's relationships with the Western hemisphere. On one side, diverse and even contradictory views of indigenous peoples were transfigured by the image of l'homme sauvage. The primitivity of America's indigenous was unquestioned in this narrow understanding even though it was open to both romantic and progressivist interpretations. On the other side, debates about the Americas in general assumed the tones of an evolutionary philosophy of history which was equally denigrating to the descendants of the Spanish conquerors (Canizarez-Esguierra). Arguments raged between Europe's 'armchair philosophers' (Voltaire, de Pauw and Raynal) who generalised the discourse of savagery to all the inhabitants of the Americas and Spanish American proto-patriots who defended their epistemological location. Between these two phases of crystallisation of civilisational difference, an inquisitive disposition to Amerindian cultures gave way to primitivist ideologies that assigned either intrinsic vice or deep virtue to native cultures. Eighteenth century debates attest to the increasingly forcefulness of views that proclaimed the superiority of European civilisation.

This is a necessarily succinct account of the coalescence of the civilisational imaginary in the interaction of Europe and the Americas and from the first moment of their calamitous encounter. Arnason's scarce but pithy comments on the Americas distinguish the tremendous upheaval of social formations during the Colombian epoch as the most dramatic and violent episode in the West’s expansion (“Civilizations in Dispute” 290). However, he does not consider it a historical entanglement of civilisations in a manner comparable to the West's other encounters. To arrive at a different conclusion, the Amerindian cultures that were at its centre would have to be recognized as civilisational forms, based on the lively and indeed 
interconnected cosmologies that they created and the economic networks that they built up. The Mesoamerican civilisations are recognized as such, but they draw one telling remark only: that they were mostly isolated from each other and did not generate any significant intercivilisational encounters. This is open to debate on two points. Firstly, there is widespread evidence of deep connection up and down the middle Americas between the territories of the Incas and the lands of the Navajo (Brotherston 13-28; Weaver). A picture of cultures and states in isolation leaves out the common cosmological signs that form the horizon of Amerindian myth, the regularity of trade and the similar linguistic structures unifying several language groups. Moreover, a shared worldview of relationships to creation and to land was common to otherwise diverse sets of mythic beliefs (Mills 422-512). On the whole, Arnason's point here overlooks the ample connections Amerindian societies clearly had with each other.

Secondly, it must be conceded that the degree of mutual reflexivity that defines intercivilisational encounters is absent. Even so, when examined in New World American contexts, the image of civilisational interaction starts to look different and warrants a different kind of approach. To begin with, it is evident that Mesoamerican civilisations were not original formations. They were accretions that had built up on the absorption and transformation of elements of cultures they had succeeded or indeed conquered. This is a kind of intercultural change which was an abiding feature of their development. For present purposes, however, there is an additional point to make. Spain's conquest and colonisation of this world had intercultural consequences, especially where the devastation of indigenous peoples was not as extensive. There is thus intercultural creation even against a backdrop of cultural desecration and extermination. Examination of the consequences of the great collision should take into account two kinds of cultural effects. Firstly, high rates of survival in New Spain (Mexico), the 
Amazonian region and the Andes provided a radically distinct source of symbolic and mythical meaning for Creole and republican societies. Secondly, the indigenous presence forced an intercultural impact on European thinking and on successive American societies. The early modern Renaissance is an instance of this second effect. The place of the Americas in the Renaissance realignment of culture is well established (Elliot 1-27; Pagden 17-49). Plant, animal and food species, and words, ideas and people exchanged across the Atlantic directly informed interpretations and metaphors of classical traditions. Europe's civilisational consciousness-its 'imaginary' in the terms that I set out above—was nourished by received ideas on the Americas and its supposed primitivity. The latter circulated widely in Europe establishing a shared fund of understanding. From that fund, metaphors of savagery could be drawn that set standards of progress with which Europeans could persuade themselves of their essential civility. Overall, this degree of cultural transmission highlights a substantial intercultural dimension of the Colombian collision which cannot be ignored, even though it equally cannot be characterized as an intercivilisational encounter.

Arnason's notion may have limited applications in the American scenario, but it would be wrong to conclude that he contributes little more to a theory of civilisational meaning. He develops a second conception of civilisation out of a post-phenomenological understanding of world interpretation. More detailed consideration shows how this might constitute a theory of the intercultural potential of specific civilizations, which is also simultaneously a study of forms of closure that particular societies institute. The first kind of interculturality that Arnason puts forward is internal to civilisations. Taking his cue from post-phenomenology (specifically an interpretation of Merleau-Ponty), he locates cultural meaning in what he describes as 'world articulation', but which might be formulated as 'world interpretation' (Adams 54-8). 
Interpretation of the world can augment the inter-cultural capacity of particular cultures and societies. How this occurs might be a research task for sociology. But it has been taken up in philosophy in an examination of civilisations as interpretive re-makings of the world. Importing this insight into comparative sociology, we can see that cultural encounters involve the imposition of models. This establishes not only a paradigm of how to do things (construct governments, develop economies etc) but a horizon which can include an internal capacity for critical reflection and revision. Vitally, this means an ability to absorb aspects of other models as well as imposing or variously setting models for post-colonial societies. In this sense, to talk meaningfully about civilisations necessitates some focus on the field of cultural interpretation of other societies, according to Arnason.

If this much is so, then we have a clue for studying the historical experience of mutual understanding and the aptitude for it. Arnason's own substantive studies show up the variety of forms of openness towards the world, but also for the potential for defensive and obstructive responses. Thus, he warns against developing a general theory of civilisations of the Parsons variety. He is at pains to stress a hermeneutical sensibility. Reinterpreting this emphasis in terms used by Parsons’ some time opponent C Wright Mills, we might say that theorists of civilisations must exercise the cultural receptiveness of the sociological imagination. Arnason's extensive treatment of the historical experience of Japan—-that 'world watching' civilisation in Roland Robertson's words (85) - is a clear example. It is worth stepping away from the scenario of Atlantic modernity momentarily to consider this exceptional civilisation. For Arnason, the defining characteristic of Japan's civilisational trajectory has been its relationship to the region (particularly China) and then to a global context, particularly the Western states it began to interact with in the nineteenth century (“Social Theory and Japanese Experience”). Its carefully 
calibrated and purposively organised relationships with the outside world from the sixteenth century on accorded with an early modernity. Even during its phase of maximum withdrawal, it continued to evaluate its mode of relation to the outside world. Simultaneously, it reshaped its special identity. This period has often been characterised as one of self-isolation, but this is a significant misjudgment. The strategies and calculations of Japan's elites were not set by an essential fetish for exclusivity. Rather, the nature of its dispositions to the wider world involved an examination of multiple cultures (including their own) as they interacted with one another. The 'opening to the West' in fact entailed a far-reaching reassessment of Japanese traditions, of the example of China and the start of a program of transformation of the country. In this sense, it could be, at most, described as a process of 'intercivilizational learning' (435). The chief antecedents of nationalism were present throughout this whole period and resulted in the early modern unification of the state and the sharpened definition of particularist identity. It is even exemplified in the postwar economic takeoff which was designed around planned economic and cultural multilateralism. This reflected self-transforming relationships with the outside world. But it vitally depended on a particular kind of developmentalist regime in the 'normalised' postwar democratic state. Reassessment of cultures Japan touched and its own cultural developments was an abiding part of this modernity.

This brings our attention to Arnason's second type of interculturality. His examination of intercivilisational interaction marks out his understanding in all his studies. The 'life' of civilisations emerges from their sustained relationships or their 'context', to use the term favoured by Arnason. Expanding the scope of civilisational analysis to a typology of multiple formations has proved insufficient. An image of closed 'families' of societies has marred past research and now finds a parallel in Huntington's much critiqued clash-of-civilisations thesis. A 
path away from Huntington's narrow analysis (not to mention his political counsel) lies beyond mere typology. If an objectivistic conception of civilisations has heuristic purpose, then it lies in the examination of the full range of contacts and interaction between (in Arnason's terms) 'civilizational complexes'. On this basis, he aims for a 'phenomenology of encounters' that is in tune with the first type of interculturality (“Understanding intercivilizational encounters” 39). Interaction should be taken here in the broadest sense involving three types. Firstly, dialogue, study, representation, diplomacy and trade are the most common modes of contact. Secondly, the diffusion of political ideas, religions, forms of administration and hard technologies indicates and promotes mutual reflexivity. Finally, account should be taken of the modes of conquest, domination and warfare. Thus even in the context of colonial domination (the case of European domination of the Americas is especially salient in this regard) there is reciprocity in the relations between two intersecting cultures and societies, albeit highly unequal. This is a sign that there is always an interpretive dimension to the function of power. Arnason's awareness of the three types reveals that he assumes porosity and not closure. However, the extent to which civilisations experience interaction and intercultural engagement varies from one case to another, as does the quality and consequences of interaction.

This fixes firmly on the problematic of the comparative interculturality of actuallyexisting civilisations. Arnason's main innovation comes to the fore here. The focus on exchange and engagement is the 'mutually formative' element of civilisations ("Civilizations in dispute" 287). In other words, civilisations 'exist', or are meaningful, mainly to the extent that they generate encounters with one another. How patterns of meaning, power and wealth form therefore depends on the receptivity of societies to cultural encounters, which in turn may shape them and their ways of interpreting the world. This is the source of cultures that are highly 
reflexive and detached both at once and engage in learning and borrowing, which often involves secondary and tertiary processes of transformation. His post-phenomenology of meaning distinguishes this method of comparative sociology from that of world historians such as Toynbee. Critical reviews of Arnason's work draw out tensions and areas not satisfactorily addressed. For example, Salvatore ( $\underline{\text { Review)}}$ ), in a complex assessment of the strategies in Arnason's work, poses two abiding problems, which Arnason does not overcome despite genuine and extensive efforts. The problem of civilisation-in-the-singular persists, if for no other reason than the fact that Western social theory dominates the field of this discussion. Secondly, the fact that transcivilisational processes which loom so large in the twenty-first century are discussed all-too-briefly even though—in Salvatore's eyes — they offer the most relevant and powerful way of defining civilisation. Islam is a case in point; it is better defined as a transcivilisational process rather than an objective region based on a world religion. As an interjection, I would say that this is the general field of intercivilisational entanglement which Arnason has begun to set out. At the very least, the notion of civilisational encounters has something rich to offer the interculturality that Salvatore highlights. However, there is another objection to Arnason's approach which could be raised at this point to do with those intercultural encounters which do not figure in civilisational theory. I will leave that for the moment in order to look at another sociologist whose work that might address the compelling criticisms that Salvatore raises.

Said Arjomand fleshes out the notion of intercivilisational encounters in his more recent work ("Political culture"). Moving out of the conventional framework of the sociology of religion, he re-visits the development of Islamiciate civilisation from the perspective of transfers between societies. Following Eisenstadt's paradigm of Axial Age transformations, he focused on how broad cultural traditions were established after the initial outgrowth of Islam ("Political 
dimensions"). Later, he revised this view substantially, adopting a more complex view of the development of heterodoxy in Shi'ite Islam. What has been underestimated in the development of Islam's political horizons is the long term impact of the medieval encounters with the West. This involved not only the transfer of ideas, but also institutions and modes of learning. The Middle Ages were also a period of intense intercivilisational learning for Islamic states, which set themselves up as the major nodes of cultural exchange in Southern Spain and Persia. They drew on Indian and Chinese science and Greeks politics and philosophy. While this effervescence declined, its legacy was bequeathed to subsequent political traditions and informed the dualism of constitutional rule and theocratic law in modernity. There's no space to explore this here and it is quite beyond the current writer's area of expertise. What is telling is that Arjomand's emphasis on intercivilisational flows serves to throw into relief the intercultural exchanges that seem to have formed a basis sketching out the dynamics of Islamic modernities. Earlier intercultural trends in his work surface more clearly in this redirection in his thinking.

\section{Ontologies and dynamics: is there an intercultural dimension in Eisenstadt's work?}

Shmuel Eisenstadt is, without question, the most recognized figure in this field. His work on Axial Age civilisations set a landmark in comparative sociology and created a new research agenda around the study of cultural ontologies, or systems of meaning based on a distinction between higher and lower levels of reality. There have been criticisms of this program of research which have resulted in revisions and theoretical re-direction. Eisenstadt's general statements on the significance of intercivilisational encounters hold out hope for an examination of the intercultural potential of different ontological orientations. In his published research on 
Judaism as civilisation, China, India and Islam, the hope is not fulfilled as it might be. His very good book on Japan is a notable exception in this respect as it details the ontological relationship between immanent and transcendental elements in an unusual combination ("Japanese civilization"). Overall, however, detailed exploration of the intercultural does not take place in Eisenstadt's large-scale studies as it does in Arnason's.

Eisenstadt's concept of civilisation presents a conceptual problem that should be summed-up before going through his substantive analysis of the distinct modernities of the Americas. Above it is noted that his work sits on the edge of objectivistic and imaginary notions of civilisation. In truth, the theoretical and methodological approach of his analysis leans towards the objectivistic side. He is less able to productively explore the intercultural dimension than Arnason for this reason. In addition, his framework of the sociology of religion has been a central focus of the development of the whole civilisational paradigm. While this is helpful in setting out the civilisational dynamics of institution-formation and long term transformation of world views, it is not a fertile field for the study of interculturality. This has been a characteristic feature of the paradigm to such an extent that some critics have claimed it is a sociology of the world religions disguised as new science. ${ }^{2}$ However, there are more urgent issues with the authority held by the sociology of religion in civilisation studies. It risks neglect of 'other patterns of meaning' (Arnason "Civilizational analysis” 26). Moreover, other social dynamics that have assumed a civilisational character are overlooked. American examples of such dynamics draw attention to some of the important features of Eisenstadt's comparative sociology.

The Americas has not received nearly as much treatment by Eisenstadt as other identifiable civilisational areas. Indeed, in general there are few civilisations-analytic studies of 
the Western hemisphere. Eisenstadt has written one definitive article that is a highly original statement (2002). In earlier writings, American societies were regarded as case studies, but their distinctiveness as separate modernities was not tested ("Modernization” 55-67, 84-98; "Patrons" 99-116). In the mid-1980s, the conventional view of modernity came into question. The proposition developed that the United States should be understood as a separate modernity-as Tocqueville had advised-along perhaps with the Latin Americas ("Patterns” vi-vii). In this context, Eisenstadt's grasp of American modernities as distinct patterns intersected with the maturation of the research program on Axial civilisations ("The origins"), though there is no clear connection between the two. When reformulating landmark theoretical statements by Karl Jaspers, Benjamin Schwartz and Eric Voegelin, the Americas did not receive separate treatment, although they could be regarded, faithfully to the original thesis, as a radical extension of the Western trajectory and therefore a distant derivative of its Axial breakthrough. General questions about the status of Axial civilisations surfaced in the late 1980s and prompted extensive debate (Arnason et al 1-8). They compelled revision of the conceptual basis of Eisenstadt's initial work. However, none of those questions directly addressed the challenge that Atlantic historical experiences pose to the heuristic value to comparative analysis of the concept of Axial civilisations or axiality, even if the Americas sit predominantly outside of the main Axial constellations or at a remote distance from the original Western breakthrough.

The latest essay is the single most important treatment of Atlantic modernity, even though it is relatively short ("The civilizations"). In critique of Louis Hartz's thesis that American societies were 'fragments' of Europe, Eisenstadt identifies four civilisational dynamics which differentiate America modernities as distinct formations in world history: 
1) The collective identities that have crystallised are only faintly primordial compared to other societies. The newness of New World formations means that a sense of antiquity is not felt as it is in the nation-states of Europe. There is a 'relative weakness of primordial criteria in the definition of their collective identities' (44). This is especially evident in language, territoriality and historicity. It should be said that Eisenstadt is referring to European-American identities here and not indigenous peoples.

2) The social and political orders of American modernities represent transformations of metaphysical premises emerging from the schism of the European Reformation. In Eisenstadt's view, there area two basic visions of the social order at work: pluralism and civic equality juxtaposed to hierarchical ethos and corporatist patterns of social relations. The political patterns of the US and Latin America diverge from one another as a result of this root conflict in social foundations.

3) The institutional patterns of different American societies exhibited contrasting dynamics. However, Eisenstadt sees these splitting into two overarching models that contrasted with each other and also with Western Europe. There are, in this sense, two Americas in his perception. A metaphor of the Americas as a 'mirror' of Europe and the Protestant northern and Catholic southern continents as 'mirror images of one another' (44) is presented.

4) Unique modernities emerged out of the long cross-Atlantic confrontation with Europe; that is, unique interpretations of their own modern conditions. The European powers that had given birth to the American colonies were not 'alien' powers in such reckoning. Instead, they were related societies generating institutional images which Americans 
could fashion new social forms from. Always, this was a 'reflexive exercise in coming to terms with their own other origins.' (45)

These are a précis only of Eisenstadt's article. The comments below only address aspects of the analysis with implications for a study of the intercultural historical experiences of the Atlantic figuration. They pave the way for some critical remarks on further work that civilisational sociology needs to do to analyze the complexity of forms of interculturality.

There are three points on which to commence a critical appraisal of Eisenstadt's case for the distinct Americas. Firstly, the impact of indigenous and African civilisations is generally underemphasised. The range of vision of civilisational confrontation is thereby too narrow to take measure of the intercultural exchanges that have shaped American societies. Thus, while there was no irresolvable opposition between European and settler forces (mobilising their respective identities), it is very clear that there has been a long confrontation with African and indigenous-American civilisations which has profoundly shaped the mode of being-in-the-world of modern Americans. The diminution of cultural influences from these sources is recognition of the environment of asymmetrical power in which they had to subsist. At the same time it echoes a degree of indifference evident in civilisational studies with respect to indigenous societies. Post-colonial critique has highlighted past societies conquered by the West that have been either excluded from, or misjudged within, the objectivistic audit of civilisations. While this is an overgeneralized and un-nuanced appraisal of social theory, it does underline issues unresolved in the paradigm about social formations that are non-stratified and possibly stateless, but which have sophisticated cultural complexes. This invites some re-thinking of the conceptual apparatus of 
contemporary civilisational theory. The case of the Americas provides the strongest argument that indigenous formations can be involved in a lasting zone of inter-civilisational engagement.

Secondly, although Eisenstadt highlights how Europe's religious conflicts formed the ontological horizons of Euro-America's colonial elites, he shows no interest in the intercultural works of settler-Creole thinkers or the intelligentsia that emerged from the republican revolutions. He does highlight the intellectual conditions in which they flourished. However, no consideration is given to how interpretations in politics, ethics and (importantly for the present theme) ethnology have augmented American versions of modernity. Three vital traditions of intercultural interpretation had a well chronicled impact. The first emerged from Jesuits mission work and is referred to briefly above. Evident in the writings of important Spanish-American thinkers are threads of intercultural thinking that I argue, following Kurasawa (1-33), exhibit an ethnological imagination. Clerical intellectuals endeavored to encapsulate the works of Mesoamerican and Ando-American civilisations. They carried out transliteration and translations of indigenous history and myth by working in the interstices of European philosophy and extant Mexica and Incan cultures. According to Brading, distinct ethnologies of Amerindian civilisations are evident in the work of sixteenth and eighteenth century Jesuit clerics and Creole republicans, in particular Carlos Siguenza y Gongora Francisco Clavijero and Juan Pablo Viscardo (“The First America”). America’s Jesuits engaged in lively polemic with philosophercritics of the Hispanoamerican culture after the notorious 1767 expulsion of their order from the Spanish territories. As Rosales documents so well, they regrouped in Italy, where they formed a school of sorts with a prodigious output of intercultural philosophy ("Francisco Xaviar Clavijero"). In that environment, they underwent a de-familiarisation of their own societies and, in a way, the memories of their own experiences in American missionary work. Sympathy for 
the indigenous - in the sense of comprehension-emerged in this space distant from the familiarity of Renaissance Europe.

Their perspectives in the sixteenth and eighteenth centuries fuelled a minor current of Indian revivalism which, in turn, enlarged the second intercultural tradition: Creole republicanism. This tradition is of a different grade of interculturality, more limited in its achievements, which were coeval with what is today remembered as Enlightenment trends. Its chief proponents were Servando de Mier, Jose San Martin, Andres Bello, Francisco Miranda and Simon Bolivar. They learnt from all models but mimicked none in their entirety. They learnt also from direct experience (Miranda and Bolivar particularly wise after the Jacobin interlude in France). ${ }^{3}$ The social thought of the French philosophes remained a significant strand in this current of politics. However, the United States was an inspirational living polity for these Americans who defied Hispanic domination. It also sheltered them during periods of their lives, as did Britain. Constitutional monarchy was another polity with appeal for those Creoles who maintained links with the liberal minority in Spain. Creole thinkers forged their republicanism at an intersection of Euro-American political ideologies. Bolivar personifies this best. His republic of 'good citizens' was cautiously crafted out of elements of European liberalism, Rousseau's social philosophy, the examples of revolutionary France and the US and histories of Spartan, Athenian and Roman statehood (Roniger 79-105). Native movements also exercised strong influence. They could not be ignored by new Creole patriots, especially in Peru. Their models of Ancient monarchy and empire were fused with contemporary liberal and republican examples in the mélange of Creole patriotism. If the works of the new patriots add up to a kind of founding political tradition, then there can be little doubt that subsequent Latin American nationalisms related ambivalently to them. How nationalist visions were built on partial selection from the 
doctrines of Creole patriotism is not directly relevant to the current essay and is better left to the literature on this tradition. ${ }^{4}$ However, it can be confidently concluded that the juncture of nineteenth century Creole patriotism had a prominent intercultural dimension.

The third current is a tradition of Latinity. It has roots in the humanist backlash against positivism that coalesced in Latin America in the early twentieth century. Though influenced by Parisian trends this was actually a self-styled Americanist movement. It stood apart as it coalesced against a backdrop of populist reaction against oligarchic rule, changing patterns of class formation and elevation of mestizaje and indigenous cultures (Larrain 92-108). PanAmericanism developed from the inspiration of American writings by Marti, Bilbao, Rodo and Vallejo. As their imagery of 'our America' spilled over into all arenas of culture, the landscape of American expression differentiated asserted a southern position. It stressed its distinctiveness and its diversity, although there is debate about this aspect of its legacy sparked by post-colonial perspectives (Fornet-Betancourt 1-15). Notwithstanding those critiques, the very reason for its existence turns on the tension of unity and vast diversity in Latin American societies. It had to forge perspectives in the interstices of cultures. The three traditions give a clue as to how diverse and complex the ideological landscape of the distinct Americas was. They do so by pointing to the diversity and distinction of perspectives in the Spanish Americas, which are often assumed to be relatively homogenous. It is problematic to subsume this complexity under Eisenstadt's limited range of cultural and social premises that were derived from the formative European cultures of the Atlantic world.

The third issue that refers to a civilisational aspect of Eisenstadt's comparative sociology has to do with religious conflict and civilisation. Civilisational theory is closely implicated in the sociology of religion. It produces great insights. But it also limits the range of dynamics that can 
be considered in depth. As argued in the passages above, over a five hundred year period, the New World has generated multifaceted political and cultural interpretations that do not figure prominently in Eisenstadt's analysis of social and cultural premises. Three short points can be made in lieu of a broader argument following this point. First of all, the lack of consideration of vast array of indigenous forms of spirituality seems, at first sight, to be a glaring omission. It makes sense, of course, when one considers that Eisenstadt's sociology of religion is framed by the prominence of the Axial transformations at the heart of the world religions. Any fuller examination of intercultural spiritual patterns and combinations in American modernities would need to find other principles to start from. Secondly, the formative religions of settler colonies were transformed by the accumulation of ongoing immigrant experiences. This is a defining and original aspect of American modernities and is especially pronounced in the case of AngloAmerica. Peter Wagner discusses a dialectic of exile and migration as Anglo-America's ontological condition (105-22). This is unique to New World experiences and profoundly influenced an Anglo-American mode-of being in ways that exceeded the social and cultural premises of colonisation. No other parallels come to mind at all. In the Americas, there are many contrasts. Outside of the societies of British North America, religious syncretism stands out in some key cases more than inherited cultural premises. This is notable in Mexico where forms of spirituality are heavy with indigenous influences. The Indo-American zone stands out against the lands of the southern cone, which in turn differ from the Caribbean with its thickly multiracial concentrations. The implication is that there is more variability in the forceful influence of formative religious principles on subsequent social formations than is suggested by Eisenstadt's juxtaposition of Catholic-Hispanic and Protestant-Anglo America. Indeed, New World immigrant-settler dynamics should be appreciated as processes of civilisational transformation. 
Thirdly, multiculturalism is an important feature of contemporary collective identity in the United States and Canada. How and why is a matter that calls for explanation. It would seem that there are more clues to be found by going beyond the metaphysical premises derived from the New World's formative religious traditions, although this is a valid starting point.

\section{Conclusion}

In summary, the distinctiveness and variety of the Americas is not captured in full by Eisenstadt's essay, despite its bold and promising thesis. More generally, recent writings in civilisational sociology have drawn into relief processes of intercivilisational engagement. This shift draws comparative analysis away from solely objectivistic conceptions of civilisation and renders this current of scholarship a more viable candidate for intercultural research. When applied to New World American contexts, however (and this requires that we agree with Arnason when he enjoins us to consider civilisations only in context), the field takes on a different shape and should take on a different set of applications. Intercivilisationality should come into sharper focus. It does not for Eisenstadt and we need to look elsewhere to fully realize the potential of the paradigm of civilisational sociology for broad application in the study of forms of the intercultural. 


\section{Bibliography}

Adams, Suzi "Castoriadis and the Permanent Riddle of the World: Changing Configurations of Worldliness and World Articulations” Thesis Eleven 90 (2007): 44-60.

Arjomand, Said The Political dimensions of religion. Albany: SUNY Press, 1993.

—Political Culture in the Islamicate Civilization” in Eliezar Ben-Rafael \& Yitzak Sternbern (Eds) Comparing Modernities: Pluralism versus Homogeneity, Essays in Homage to Shmuel N Eisenstadt. Leiden: Brill, 2005.

Arjomand, Said and Tiryakian, Edward (Eds) Rethinking Civilizational Analysis. London: Sage, 2004.

Arnason, Johann P. "Social Theory and the Concept of Civilization” Thesis Eleven 20: 87-105, 1988

Social Theory and Japanese experience: the Dual Civilization. London: Kegan Paul International, 1997.

Civilizations in dispute: historical questions and theoretical traditions. Leiden: Brill, 2003.

—_Understanding Intercivilizational Encounters” Thesis Eleven 86: 39-53, 2006a.

“Civilizational Analysis: a Paradigm in the Making” in Robert Holton [Ed.], World Civilizations, in Encyclopedia of Life Support Systems (EOLSS), Developed under the Auspices of the UNESCO, Oxford: Eolss Publishers, 2007 [http://www.eolss.net].

_ "Marshall Hodgson's Civilisational Analysis of Islam: Theoretical and Comparative Perspectives” in Johann P. Arnason, Armando Salvatore, and Georg Stauth (Eds) Islam in Process: Historical and Civilizational Perspectives. Piscataway, New Jersey: Transaction, 2006b

Arnason, Johann P. Eisenstadt, Shmuel N. and Wittrock, Bjorn (Eds) Axial civilizations and world history. Leiden: Brill, 2005. 
Brading, David The First America: the Spanish Monarchy, Creole Patriots and the Liberal State 1492-1867. Cambridge, UK: Cambridge University Press, 1993.

Brotherston, Gordon Image of the New World: the American Continent Portrayed in Native Texts. London: Thames and Hudson, 1978.

Canizares-Esguerra, Jorge How to Write the History of the New World: Histories, Epistemologies, and Identities in the Eighteenth-Century Atlantic world. Stanford: Stanford University Press, 2001.

Eisenstadt, Shmuel N. Modernization: Protest and Change. Englewood Cliffs, New Jersey: Prentice-Hall, 1966.

Patrons, Clients and Friends: Interpersonal Relations and the Structure of Trust in Society. Cambridge: Cambridge University Press, 1984.

— (Ed) The Origins and Diversity of Axial Age Civilizations. Albany: SUNY Press, 1986.

- (Ed) Patterns of Modernity: Beyond the West. New York: New York University Press, 1987.

_ Japanese Civilization: a Comparative View. Chicago: University of Chicago Press, 1996.

— "The Civilizations of the Americas: the Crystallization of Distinct Modernities" Comparative Sociology. 1(1): 43-61, 2002.

Elias, Norbert The History of Manners. Oxford: Oxford University Press, 1978.

Elliot, John H. The Old World and the New 1492-1650. Cambridge: Canto, 1992.

Fornet-Betancourt Raul (Ed) Critica Intercultural de la Filosofia Latinoamerica Actual. Madrid:

Editorial Trotta, 2004.

Hartz, Louis The Founding of New Societies: Studies in the History of the United States, Latin America, South Africa, Canada and Australia. New York: Harcourt Brace, 1964. 
Instituto Jacques Maritain de Cuba. Pensadores Hispanoamericanos. Florida: Ediciones Universal, 1995.

Kavolis, Vytautas Civilization Analysis as a Sociology of Culture. New York: Edwin Mellon Press, 1995.

Kurasawa, Fuyuki The Ethnological Imagination: a Cross-cultural Critique of Modernity. Minneapolis: University of Minnesota Press, 2004.

Larrain, Jorge Identity and Modernity in Latin America. Cambridge: Polity Press, 2000.

Lynch, John Simon Bolivar: A Life. New Haven and London: Yale University Press, 2006.

Mills, Alice Mythology: Myths, Legends and Fantasies. Sydney: Hodder, 2005.

Pagden, Anthony European Encounters with the New World. New Haven and London: Yale University Press, 1993.

Robertson, Roland Globalization. London: Sage, 1992.

Roniger, Luis “Global Immersion: Latin America and its Multiple Modernities” Luis Roniger \& Carlos Waisman (Eds) Globality and Multiple Modernities: Comparative North American and Latin American Perspectives. East Sussex: Sussex Academic Press, 2002.

Rosales, Alfonso Martinez Francisco Xaviar Clavijero en la ilustracion Mexicana 1731-1787. Mexico: El Colegio de Mexico, 1988.

Rundell, John R “From Indigenous Civilization to Indigenous Modernities” in Said Arjomand and Edward Tiryakian (Eds) Rethinking Civilizational Analysis. London: Sage, 2004.

Rundell, John R and Mennell, Stephen (Eds) “Introduction: Civilization, Culture and Human Image” Classical Readings in Culture and Civilization. London: Routledge, 1998.

Salvatore Armando. Review of Johann P Arnason Civilizations in Dispute: Historical Questions and Theoretical Traditions. European Journal of Social Theory 10: 327-331, 2007. Spengler, Oswald The Decline of the West. New York: Random House, 1966. 
Wagner, Peter Theorizing Modernity. London: Sage, 2001.

Weaver, Muriel Porter The Aztecs, Maya and their Predecessors: Archaeology of Mesoamerica.

New York and London: Seminar Press, 1972.

Wrong, Dennis The Oversocialized Conception of Man New Brunswick, NJ: Transaction, 1998.

Zeuske, Michael Francesco de Miranda y la Modernidad en America. Madrid: Prisma Historico, 2004.

${ }^{1}$ See Rundell (201-216) for a more lengthy discussion of the objectivistic notion of civilisation.

${ }^{2}$ See Robertson (136) and Kavolis (36-7).

${ }^{3}$ On the many sources of influence in Creole republicanism, see the Instituto Jacques Maritain de Cuba ("Pensadores hispanoamericanos”), Lynch ("Simon Bolivar”) and Zeuske (Francesco de Miranda).

${ }^{4}$ See Brading ("The first America”). 